\title{
PENGARUH MODEL PEMBELAJARAN CORE (CONNECTING ORGANIZING EFLECTING EXTENDING) DENGAN MEDIA POSTER TERHADAP HASIL BELAJAR SISWA PADA MATERI LARUTAN PENYANGGA \\ THE INFLUENCE OF CORE (CONNECTING ORGANIZING REFLECTING EXTENDING) LEARNING MODEL WITH POSTER MEDIA ON STUDENT LEARNING OUTCOMES MATERIAL OF BUFFER
}

\author{
Eka Parmawatika, Ratna Kusumawardani, Iis Intan Widyowati \\ Program Studi Sarjana Pendidikan Kimia, Fakultas Keguruan dan llmu Pendidikan, Universitas Mulawarman, \\ Samarinda, Kalimantan Timur, Indonesia \\ *Corresponding Author: nana_chemistry@yahoo.com
}

\begin{abstract}
ABSTRAK
Penelitian ini bertujuan untuk mengetahui pengaruh model pembelajaran Connecting Organizing Reflecting Extending (CORE) dengan media poster terhadap hasil belajar siswa pada pokok bahasan larutan penyangga di SMA Negeri 7 Samarinda. Populasi dalam penelitian ini adalah seluruh siswa kelas XI IPA SMA Negeri 7 Samarinda. Teknik pengambilan sampel yang digunakan adalah purposive sampling sehingga diperoleh sampel penelitian yaitu siswa kelas XI IPA 1 dan XI IPA 2. Kelas XI IPA 2 merupakan kelas yang menggunakan model pembelajaran CORE dengan media poster sedangkan kelas XI IPA 1 menggunakan model pembelajaran langsung. Teknik pengambilan data dilakukan dengan menggunakan teknis tes dan teknik dokumentasi. Teknik analisa data menggunakan uji t. Nilai rata-rata hasil belajar siswa yang menggunakan model pembelajaran CORE dengan media poster adalah 74,09 dan rata-rata nilai hasil belajar siswa yang menggunakan model pembelajaran langsung adalah 67,07. Hasil penelitian menunjukkan bahwa rata-rata nilai hasil belajar siswa yang menggunakan model pembelajaran CORE dengan media poster lebih baik daripada rata-rata nilai hasil belajar siswa yang menggunakan model pembelajaran langsung. Berdasarkan hasil analisis data dengan menggunakan uji $\mathrm{t}$ diperoleh kesimpulan bahwa terdapat pengaruh model pembelajaran Connecting Organizing Reflecting Extending (CORE) dengan media poster terhadap hasil belajar siswa pada pokok bahasan larutan penyangga di SMA Negeri 7 Samarinda.
\end{abstract}

Kata kunci: hasil belajar, larutan penyangga, CORE, poster

\begin{abstract}
This study aims to determine the effect of the Connecting Organizing Reflecting Extending (CORE) learning model with poster media on student learning outcomes on the subject of buffer solution at SMA Negeri 7 Samarinda. The population in this study were all students of class XI Science at SMA Negeri 7 Samarinda. The sampling technique used was purposive sampling in order to obtain research samples, namely students of class XI IPA 1 and XI IPA 2. Class XI IPA 2 was a class that used CORE learning models with media posters while class XI IPA 1 used direct learning models. Data collection techniques are carried out using technical tests and documentation techniques. Data analysis technique uses $t$ test. The average value of student learning outcomes that use the CORE learning model with poster media is 74,09 and the average value of student learning outcomes using direct learning models is 67,07. The results showed that the average value of student learning outcomes using CORE learning models with poster media was better than the average value of learning outcomes of students who used direct learning models. Based on the results of data analysis using the $t$ test, it can be concluded that there is an influence of the Connecting Organizing Reflecting Extending (CORE) learning
\end{abstract}


model with poster media on student learning outcomes on the subject of buffer solution at SMA Negeri 7 Samarinda.

\section{Keywords: learning outcomes, buffer solutions, CORE, posters}

\section{PENDAHULUAN}

Kimia merupakan salah satu cabang Ilmu Pengetahuan Alam yang mempelajari tentang materi yang meliputi struktur, susunan, sifat dan perubahan materi serta energi yang menyertainya. Pada materi kimia terdapat pokok bahasan yang membahas tentang larutan penyangga. Berdasarkan hasil wawancara dengan beberapa siswa di kelas XI IPA SMA Negeri 7 Samarinda, diperoleh hasil bahwa materi larutan penyangga termasuk salah satu materi yang dianggap sulit. Tanpa minat dan motivasi belajar yang tinggi, maka konsep-konsep kimia dalam larutan penyangga sulit untuk dipahami sehingga akan berpengaruh terhadap hasil belajar.

Peningkatan minat dan motivasi siswa dapat dilakukan salah satunya dengan melakukan variasi model dan media dalam pembelajaran (Nurhadi, 2004). Salah satu model pembelajaran tersebut adalah model pembelajaran Connecting Organizing Reflecting Extending (CORE). Model pembelajaran CORE merupakan salah satu model yang mengajak siswa untuk aktif pada proses pembelajaran yang menghubungkan antara informasi lama dan informasi baru, mengorganisasikan sejumlah materi yang bervariasi, merefleksi segala sesuatu yang siswa pelajari dan mengembangkan lingkungan belajar (Harmsen, 2005). Model pembelajaran CORE dapat meningkatkan hasil belajar siswa (Yuwana, S.W., 2013; Wulandari, 2017).

Model pembelajaran ini diharapkan akan lebih efektif jika dipadukan dengan media pembelajaran yang sesuai, salah satunya adalah media poster. Poster merupakan salah satu media grafis yang paling tampak kekuatannya sebagai media penyampai pesan. Media grafis adalah media visual yang menyajikan fakta, ide dan gagasan melalui kata-kata, kalimat, angka, dan berbagai simbol dan gambar. Keuntungan menggunakan media poster adalah mudah dibawa kemana-mana sebagai media pembelajaran (Stevick, 1982). Poster bukan merupakan suatu metode pembelajaran tetapi guru menggunakannya untuk menggambarkan tempat, objek, orang dan hal tersebut merupakan bagian dari pengalaman siswa sehingga memudahkan guru untuk menyampaikan materi berdasarkan ruang lingkupnya (Wright, 1989). Media poster dapat meningkatkan kualitas proses dan hasil belajar siswa
(Rochani, 2009; Fenni, dkk, 2010). Poster dapat menarik perhatian siswa karena poster memiliki warna yang bervariasi dan terdapat gambar berwarna sehingga memudahkan pemahaman siswa.

Berdasarkan uraian di atas maka penulis tertarik untuk menggunakan media poster dalam model pembelajaran CORE, maka tujuan penelitian ini adalah untuk mengetahui pengaruh model pembelajaran CORE dengan media poster terhadap hasil belajar siswa pada pokok bahasan larutan penyangga.

\section{METODE PENELITIAN}

Pada penelitian ini pengambilan sampel dilakukan dengan teknik purposive sampling. Purposive sampling adalah teknik pengambilan sampel yang anggota sampelnya dipilih dari guru secara sengaja atas dasar pertimbangan pengetahuan dan keyakinan guru (Susilo, 2009). Sampel dalam penelitian ini siswa kelas XI IPA 1 dan kelas XI IPA 2 SMA Negeri 7 Samarinda.

Berdasarkan tujuan yang ingin dicapai dari penelitian ini maka teknik pengumpulan data yang dilakukan adalah dengan cara tes dan non tes. Teknik Tes ini dibagi menjadi dua yaitu posttest dan ulangan harian. Soal posttest terdiri dari 5 soal essay yang dibuat berdasarkan indikator setiap pertemuan dan diberikan diakhir pembelajaran setiap pertemuan. Ulangan harian terdiri dari 5 soal essay yang dibuat berdasarkan seluruh indikator pembelajaran dan diberikan pada pertemuan ketiga.

Teknik non tes terdiri dari dokumentasi yang berupa nilai siswa sebelum diberi perlakuan yang diambil dari nilai materi ulangan harian sebelumnya kemudian digunakan untuk melakukan uji homogenitas sampel dan pembagian kelompok agar heterogen.

Nilai hasil belajar siswa diambil melalui hasil posttest siswa untuk dua kali pertemuan dan ulangan harian pokok bahasan larutan penyangga. Persentase nilai posttest masing - masing $20 \%$ dan ulangan harian $60 \%$. Hasil belajar yang diperoleh masing masing kelas kemudian di analisa menggunakan uji t dengan taraf signifikansi sebesar 5\%. 


\section{HASIL DAN PEMBAHASAN}

Berdasarkan hasil perhitungan rata-rata nilai hasil belajar siswa kelas XI IPA 2 dengan penerapan model pembelajaran CORE (Connecting Organizing Reflecting Extending) dengan media poster sebesar 74,09 dan rata-rata nilai akhir hasil belajar siswa kelas XI IPA 1 dengan penerapan model pembelajaran langsung sebesar 67,07. Adapun rata rata nilai hasil belajar pada kedua kelas dapat dilihat pada gambar 1 .

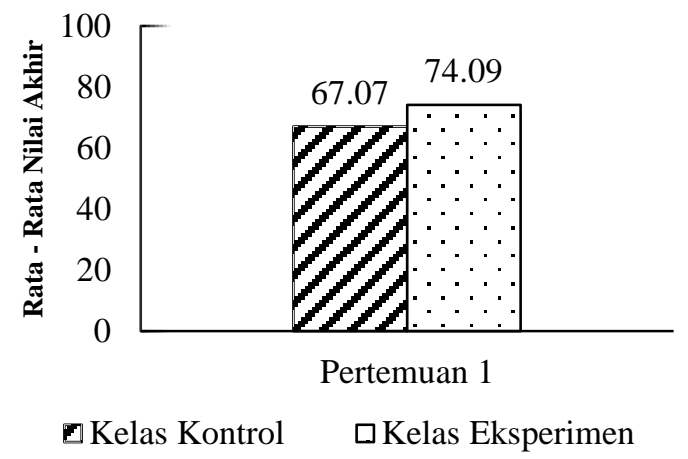

\section{Gambar 1. Rata-rata Nilai Hasil Belajar Siswa}

Berdasarkan gambar 1 dapat dilihat bahwa rata-rata nilai hasil belajar dari kedua kelas mempunyai hasil yang berbeda. Rata-rata nilai hasil belajar kelas XI IPA 2 yang menggunakan model pembelajaran CORE dengan media poster lebih tinggi daripada kelas XI IPA 1 yang menggunakan model pembelajaran langsung. Hal ini disebabkan karena model pembelajaran CORE dengan media poster memiliki keunggulan dibandingkan pembelajaran langsung.

Pada model pembelajaran CORE memiiiki tahapan yaitu connecting, organizing, reflecting dan extending. Pada tahapan pertama adalah connecting. Pada tahap ini siswa diajak untuk menghubungkan konsep baru yang akan dipelajari dengan konsep lama yang telah dimilikinya. Hal ini dilakukan melalui metode diskusi. Siswa dapat mengungkapkan konsep lama yang telah diperoleh baik itu melalui pengalaman maupun dari materi sebelumnya yang berkaitan. Pada tahap ini dapat membangkitkan motivasi siswa karena pengalaman yang pernah dialaminya ternyata berkaitan dengan materi yang akan dipelajari.

Tahap kedua adalah organizing. Pada tahap ini siswa diajak mengorganisasikan informasi-informasi yang diperoleh seperti konsep apa yang diketahui, konsep apa yang dicari, dan keterkaitan antar konsep apa saja yang didapat. Pada tahap ini siswa diajak untuk dapat membangun pengetahuannya sendiri berdasarkan konsep lama dan konsep baru yang telah didiskusikan pada tahap connecting. Tahap connecting ini, siswa berdiskusi dengan teman sekelompoknya hingga diperoleh kesimpulan konsep. Guru berperan memancing dan mengarahkan pola pikir siswa dalam diskusi.

Tahap ketiga adalah reflecting. Pada tahap ini siswa diajak memikirkan kembali konsep-konsep yang telah diperoleh pada saat diskusi di tahap organizing, apakah konsep-konsep yang diperoleh sudah benar- atau belum. Konsep yang sudah benar akan diberi penguatan oleh guru, dan konsep yang belum benar akan diluruskan oleh guru. Penguatan konsep ini bertujuan untuk mengendapkan apa yang baru saja dipelajari siswa sebagai struktur pengetahuan yang baru. Tahap ini dapat meningkatkan keingintahuan siswa terhadap suatu konsep yang belum dipahaminya dan meningkatkan rasa percaya diri dalam diri siswa terhadap konsep yang telah dipahaminya. Diskusi yang baik dapat meningkatkan berfikir reflektif siswa. Hal ini sesuai dengan pendapat O'Flavohan dan Stein, bahwa berfikir relektif dapat berpengamh secara signifikan terhadap kemampuan siswa dengan merefleksikan pada interaksi dan pada substansi berfikirnya (Jacob, 2011). Pada tahap reflecting ini siswa terbantu dengan adanya media poster yang berisi konsep konsep dalam bentuk simbol dan gambar. Poster ini semakin meningkatkan ketertarikan siswa dalam mempelajari materi larutan penyangga.

Tahap keempat adalah extending. Pada tahap ini siswa diajak memperluas pemahaman dan pengetahuannya tentang kesimpulan apa yang telah diperolehnya melalui tahap reflecting. Perluasan pengetahuan ini harus disesuaikan dengan kondisi dan kemampuan yang dimiliki siswa. Pada tahap ini siswa diajak mengerjakan soal-soal pada Lembar Kerja Siswa (LKS) kemudian memaparkan jawabannya di depan teman-temannya untuk memperoleh tanggapan dari teman-temannya. Pada tahap ini dapat meningkatkan rasa percaya diri siswa dan dapat melatih siswa dalam mengerjakan soal soal aplikasi konsep. Hal ini semakin meningkatkan pemahaman siswa. Siswa dapat saling bertukar pikiran dengan teman sebayanya, dimana teman sebaya ini akan memaparkan jawaban LKS nya menggunakan bahasa yang lebih mudah dipahami dan teman yang tidak atau kurang paham berani untuk bertanya dan memberikan tanggapan. Hal ini dapat meningkatkan pemahaman siswa. 
Untuk mengetahui pengaruh penerapan model pembelajaran CORE dengan menggunakan media poster terhadap hasil belajar dilakukan uji statistik menggunakan rata-rata nilai hasil belajar yang diperoleh siswa. Di dukung dengan hasil uji t. Berdasarkan hasil perhitungan diperoleh bahwa nilai $\mathrm{F}_{\text {hitung }}<\mathrm{F}_{\text {tabel }}$ yaitu $1,29<1,84$ maka Ho diterima sehingga kedua sampel berasal dari populasi dengan variansi homogen. Kemudian dilanjutkan uji $t$ dengan perhitungan hipotesis diperoleh $-\mathrm{t}_{\text {hit }}<-\mathrm{t}_{\text {tabel }}$ yaitu $-3,32<-2,00$ pada taraf signifikan $5 \%$ yang berarti bahwa Ho ditolak dan Ha diterima berarti dapat diketahui bahwa terdapat pengaruh penggunaan model pembelajaran CORE (Connecting, Organizing, Reflecting, Extending) terhadap hasil belajar siswa pada pokok bahasan larutan penyangga dengan menggunakan media poster di SMA Negeri 7 Samarinda.

Berdasarkan hasil yang diperoleh dengan adanya penggunaan model pembelajaran CORE (Connecting Organizing Reflecting Extending) dengan media poster diperoleh nilai rata-rata hasil belajar siswa kelas IPA 2 lebih tinggi dibandingkan dengan nilai rata-rata hasil belajar di kelas IPA 1, hal ini memberikan hasil yang positif dimana aspek kognitif siswa dapat meningkat dengan baik, sehingga dapat dikatakan bahwa model pembelajaran CORE dengan media poster dapat berpengaruh terhadap hasil belajar siswa.

\section{PENUTUP}

\section{Simpulan}

Berdasarkan hasil penelitian dapat disimpulkan bahwa terdapat pengaruh model pembelajaran CORE (Connecting Organizing Reflecting Extending) dengan media poster terhadap hasil belajar siswa pada pokok bahasan lalutan penyangga. Nilai rata-rata hasil belajar siswa yang menggunakan model pembelajaran CORE dengan media poster lebih tinggi daripada nilai rata-rata hasil belajar siswa yang menggunakan model pembelajaran langsung.

\section{Saran}

Berdasarkan penelitian yang telah dilaksanakan, maka dapat peneliti ungkapkan saransaran sebagai berikut perlu dilakukan inovasi dalam menggunakan model pembelajaran CORE dengan berbantukan media lain yang lebih efektif sehingga dapat meningkatkan kemampuan berfikir kritis, minat dan motivasi siswa dalam belajar kimia.

\section{UCAPAN TERTMAKASIH}

Penulis mengucapkan terima kasih dengan segenap ketulusan hati kepada pihak-pihak yang telah membantu dalam penyusunan skripsi ini, antara lain Bapak I Putu S.Pd., M.Pd selaku Kepala SMA Negeri 7 Samarinda dan Bapak Sutarman S.Pd selaku guru bidang studi kimia SMA Negeri 7 Samarinda yang telah banyak membantn selama proses penelitian.

\section{DAFTAR PUSTAKA}

Artasari, Yulia, dkk. 2012. Pengaruh Model Pembelajaran Connecting Organizing Reflecting Extending (CORE) Terhadap Kemampuan Berfikir Divergen Siswa Kelas IV mata Pelajaran IPS. Ejournal.undiksha.ac.id

Fenni, Sabsul, dkk. 2010. Penggunaan Media Poster Dalam Pembelajaran Fisika Untuk Meningkatkan Hasil Belajar Siswa Kelas VIII SMP Negeri 2 Kuanta Hilir Seberang

Harmsen, D. 2005. Journal critique\#2. http:www.tsclient/A/Daniell Harmsen.htm

Jacob, C. 2011. Rcfleksi pada Refleksi Lesson Study (Suatu Pembelajaran Berbasis Metakognisi) .Jurnal Pendidikan Matematika FPMIPA. Bandung.

Nurhadi. 2004. Kurikulum 2004 : Pertanyaan dan jawaban. Jakarta : PT. Grasindo.

Rochani, Siti. 2009. Penggunaan Pendekatan CTL Dilengkapi Media Poster Untuk Meningkatkan Kualitas Proses dan Hasil Belajar Siswa Pada Materi Pokok Sistem Periodik Unsur Kelas X Semester Gasal Di SMA Negeri 1 Jakenan, Pati Tahun Pelajaran 2009/2010. Surakarta: Universitas Sebelas Maret.

Susilo, 2009. Penelitian Tindakan Kelas. Yogyakarta: Pustaka Book Publisher.

Suyatno. 2009. Menjelajah Pembelajaran Inovatif. Sidoarjo: Masmedia Buana Pustaka.

Stevick, Earl W. 1982. Teaching and Learning Language. USA. Cambridge University Press.

Trianto, 2007. Model-Model Pembelajaran Inovatif. Jakarta: Prestasi Pustaka.

Usman, Moh Uzer. 2000. Menjadi Guru Profesional. Bandung: Remaja Rosdakarya.

Yuniarti, Santi.2013. Pengaruh Model CORE Berbasis Kontekstual Terhadap Kemampuan Pemahaman Matematik Siswa. Jurnal PRODI PMT STKIP. Siliwangi Bandung.

Yuwana, Siwi W.P. 2013. Keefektifan Pembelajaran CORE Berbantuan CABRI Terhadap Motivasi 
Bivalen: Chemical Studies Journal, 2018, Vol. 1, No. 2

dan Hasil Belajar Peserta Didik Materi Dimensi Tiga. Skripsi.

Wulandari, S. T. 2017. Pengaruh Model Pembelajaran Connecting, Organizing, Reflecting, Extending (CORE) Disertai Metode Mind Map Terhadap Hasil Belajar Biologi Siswa Kelas XI Di SMA Negeri 5 Yogyakarta Tahun Ajaran 2016/2017 . Skripsi.

Wright, Andrew. 1989. Pictures for Language Learning. Cambridge: Cambridge University Press. 